\title{
Small-Scale Turkey Farming in Bangladesh: Farming Practices, Profitability and Supply Chain Mapping
}

\author{
M A Rashid ${ }^{1}$, M Rasheduzzaman ${ }^{2}$, MSK Sarker ${ }^{1}$, S Faruque ${ }^{1}$, Md Salauddin Palash ${ }^{2} \&$ NR Sarker ${ }^{1}$ \\ ${ }^{1}$ Poultry Production Research Division, Bangladesh Livestock Research Institute (BLRI), Savar, Dhaka-1341, \\ Bangladesh \\ ${ }^{2}$ Department of Agribusiness and Marketing, Bangladesh Agricultural University, Mymensing-2202, Bangladesh \\ Correspondence: M. A. Rashid, SSO, Poultry Production Research Division, Bangladesh Livestock Research \\ Institute (BLRI), Savar, Dhaka-1341, Bangladesh. E-mail: marashid31@yahoo.com
}

Received: May 17, 2020 Accepted: June 9, 2020 Online Published: July 16, 2020

\begin{abstract}
The study was conducted to know the existing turkey production system, supply chain mapping, and identifying the prospects and problems of turkey rearing in some selected areas of Bangladesh during October 2019 to December 2019. A total of 100 turkey raisers were surveyed following convenience method of sampling technique. The primary data were collected, analyzed accordingly and tabular presentation method was applied with the help of simple descriptive statistical measures e.g. frequency distributions, percentage, sum and means to illustrating the results. Profitability analysis was done on the basis of variable cost, fixed cost, return by using arithmetic means and percentages. The study revealed that 87 male and 13 female respondents were surveyed, of them cent percent found educated. About $56 \%$ turkey keeper's main occupation was business, $27 \%$ service and $12 \%$ in farming while $88.57 \%$ involved with farming as secondary sources of income. Average landholding for homestead, cultivable and non-cultivable was 24.40, 129.71 and 29.47 decimal, respectively. About $59 \%$ farms started for commercial purpose, $32 \%$ for non-commercial purpose and $9 \%$ for both. About $60 \%$ respondents kept less than 50 turkeys and only 2\% kept 501-1000 turkeys. Among the surveyed farms $55 \%$ stopped their operation and $45 \%$ farms found running their business. Among the running farms cent percent were small-scale group. The average feed intake was 192.13 grams per day per bird at 20 weeks of age. Turkey laid on an average 139 eggs a year irrespective of variety and for hatching poults, the fertility and hatchability rate found between 65 to $100 \%$ and 50 to $90 \%$, respectively. About $28 \%$ farmers experienced the deaths of turkey because of Cold, Pox, Ranikhet, Bird flu and unknown cases and $69.47 \%$ farmers took veterinary advice from Upazila Livestock Hospital and rest from other sources. Farmers to consumers were the most common and widely used marketing channel for egg, chick and adult turkey. The market intermediaries of turkey farm carried out different marketing functions e.g. buying and selling, pricing, transportation, sorting, distribution and market information. The average net return and benefit-cost ratio was BDT 127838.04 and 1.38, respectively for 50 turkeys per year. In the study, turkey rearing found some comparative benefit over chicken and ducks e.g. higher weight gain, forage eater, lower diseases rate and suitability for the country. The main problem of turkey rearing identified as market instability, lack of quality turkey feed, higher feed price, lack of proper marketing facility and training on turkey farming. In conclusion, the small-scale turkey farming could be a viable source of income for the rural people of Bangladesh after taking some remedial steps by the Government of Bangladesh for the aforesaid hindrances faced by the turkey farmers.
\end{abstract}

Keywords: small-scale, turkey farming, profitability, supply chain, problems and prospects

\section{Introduction}

The livestock sector has been playing a vital role in the socio-economic development and contributing significantly to the overall agriculture sector in Gross Domestic Product (GDP). Livestock sub-sector contributes 35 to $40 \%$ alone to overall agriculture sector and $1.53 \%$ of the total GDP (MOFL, 2019). It is labor intensive and fast income generating sector contributes significantly to poverty reduction as well as employment generation for the poor and marginal people. Already Bangladesh achieved self-sufficiency in meat production and very close to selfsufficiency in egg production (DLS, 2019). The poultry population in Bangladesh is estimated at 258.22 million comprising 189.26 million chickens, 67.52 million ducks, and 1.44 million of turkeys (BBS, 2019). The poultry constitutes a major portion of animal protein source of the country. As an employment and income provider, poultry sector makes a significant effect to the livelihood assets of farm households. Thousands of smallholders 
along with large-scale commercial poultry producers supply the poultry meat and eggs for domestic consumption. It was reverse before 1990s, backyard poultry were the sources of $98 \%$ supply of poultry meat and eggs in the country and the rest $2 \%$ would come from commercial poultry (UNDP/FAO, 1983). In those days, per capita egg and meat consumption was very poor compare to the current situation.

Turkeys are classed in the family of Phasianidae in the taxonomic order of Galliformes. The genus Meleagris is the only extant genus in the subfamily Meleagridinae. The species Meleagris gallopavo is used by humans for their meat (Crowe, 2006). They were first domesticated by the indigenous people of Mexico from at least $800 \mathrm{BC}$ onwards. The birds were first taken to Spain about 1519AD, and reaching England in 1541AD. English colonists then introduced European-bred strains of the turkey to eastern North America in the 17th century. Until about 1935, turkeys were bred mainly for their beautiful feathers not for meat, after which the breeding emphasis changed to their meat qualities (Hulet et al., 2004).

There was no concrete data on turkey rearing history in Bangladesh, but a farmer stated that he started his farm in 2014 with only 22 turkey birds brought from India (Siddiky, 2017). Farmers are rearing turkey with a limited prior experience and it is increasing gradually because of a gamey flavor of meat with lower fat content (Asaduzzaman, 2017). Turkey farming is similar to other poultry birds farming like chickens, ducks, quails, etc. and very enjoyable (Chowdhury et al., 2004). Despite being priced steeply compared to other poultry products, the demand for turkey meat is increasing which has prompted various players to set up turkey rearing farms. Turkey production is an important and highly profitable agricultural industry with a rising global demand (Yakubu et al., 2013), and it is adaptable to a wide range of climatic conditions. Besbes (2009) reported that the worldwide poultry sector consists of chickens $(63 \%)$, ducks $(11 \%)$, geese $(9 \%)$, turkeys $(5 \%)$, pigeons $(3 \%)$ and guinea fowls $(3 \%)$. Turkey grows faster like broiler chickens and become suitable for slaughter purpose within a very short time. Turkey farming for meat production is very popular than egg production in Bangladesh (Siddiky, 2017). Turkey is more resistant to disease compared to other poultry species like chicken, duck, and quail. It has also been reported that mortality rate of turkey is very low compared to other poultry bird (Sampath, 2012).

Turkey has some benefits compared to other poultries like chicken, duck, pigeon etc. but, facing problems of market demand instability, price volatility, lack of quality feed as well as higher feed price, and lack of proper marketing facility which reduce the pace of this sector significantly. Cost effective farming practices, efficient market information system and marketing channel can help turkey farmers to run the business with a reasonable margin of profits. The study was conducted aiming to know the existing turkey farming practices, status of the profitability and supply chain mapping that means how the turkey farmers transferred their produce to the end user.

\section{Materials and Methods}

\subsection{Study Area}

Turkey farming is a new entrepreneurship in Bangladesh and the young entrepreneurs from different parts of Bangladesh are trying to adopt turkey farming. The density of turkey farms is not same in all regions. Therefore, areas were chosen based on the availability of turkey farming. Thus, appropriate farm households from five were selected. The selected areas were the Mymensingh, Gazipur, Narsingdi, Narayanganj and Dhaka districts of Bangladesh (Figure 1).

\subsection{Data}

Convenience method of sampling technique was followed where a total number of 100 turkey raisers were surveyed. The number of farms surveyed in the Mymensingh, Gazipur, Narsingdi, Narayanganj and Dhaka districts was 23, 20, 20, 24 and 13, respectively. Data were collected in the month of October to December 2019. A set of survey schedule was developed with necessary corrections and modifications. After the initial development of the interview schedule, pre-testing was done to make sure that the questions were neither difficult nor unanswerable for the respondents. The primary data were collected through face to face interview with the finalized questionnaire through personal visit to the houses of the farmers. Before beginning of the interview a brief introduction about the purpose of the study was given to the respondents. Then the questions were asked in easy and understandable language and the information was recorded on the survey schedule. 


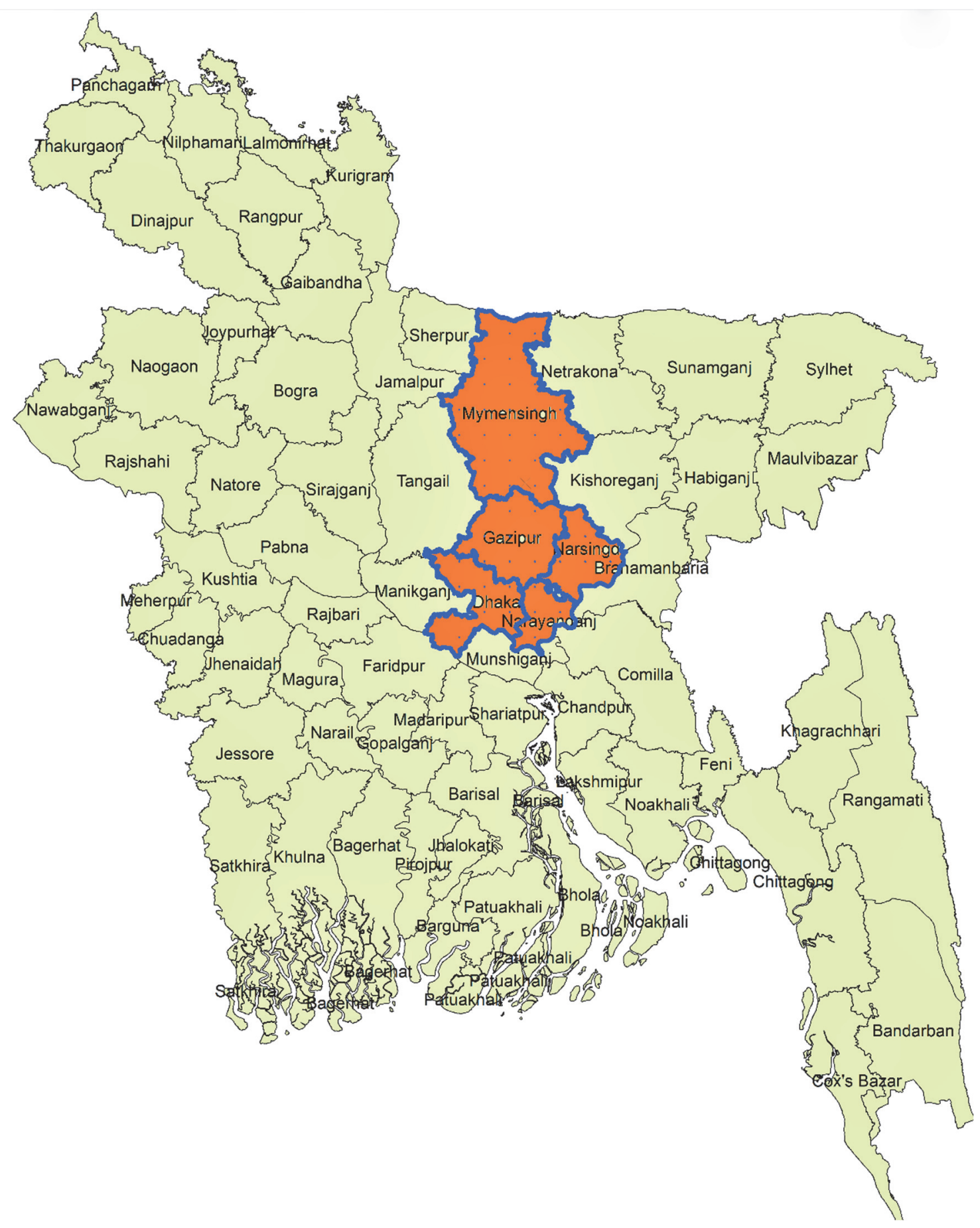

Figure 1. Selected areas for the study

Source: Author's preparation using Arc GIS 10, 2020

\subsection{Data Analysis}

Data were subjected to both descriptive statistics (such as mean, frequency and percentage) and inferential statistics which is the Pearson Product-Moment Correlation (PPMC) coefficient PPMC to show the relationship between profit in turkey production and socioeconomic variables. Microsoft Excel 365 program was used to analyze the cross section data. Descriptive analysis was used to describe the existing turkey farming practices followed by the farmers and it provides valuable information about the nature of the particular group of individuals (Best and Kahn, 2003). Profitability analysis was done on the basis of gross return, gross margins, net return and benefit-cost ratio. 
Gross return is the monetary value of total gross output; the total value of sold out turkey was taken into account as benefits of the farms at the existing market price of turkey. Therefore, the formula is:

$$
\mathrm{GR}=\Sigma \mathrm{QtPt}
$$

Where, $\mathrm{GR}=$ Gross Return; $\mathrm{Q}_{\mathrm{t}}=$ Totalturkeysold $\left(\mathrm{kg} /\right.$ farm $/$ year) and $\mathrm{P}_{\mathrm{t}}=$ Price of turkey $(\mathrm{BDT} / \mathrm{kg})$.

Gross margin was calculated by subtracting the total variable costs from the gross return, showed in thefollowing equation.

$$
\mathrm{GM}=\mathrm{GR}-\Sigma \mathrm{TVC}
$$

Where, $\mathrm{GM}=$ Gross Margin; $\mathrm{GR}=$ Gross Return; and TVC $=$ Total Variable Cost .

Here, the following net return/profit equation was developed to assess the net return of the turkey farms.

$$
\text { NR = PtQt }-\Sigma T V C-\Sigma T F C
$$

Where, $N R=$ Net Return from turkey farming $(B D T /$ year $), \mathrm{P}_{t}=$ Price of turkey $(B D T / k g), Q_{t}=$ Total turkey sold $(\mathrm{kg} /$ farm/year $), \mathrm{TVC}=$ Total Variable Cost, $\mathrm{TFC}=$ Total fixed cost.

The benefit-cost ratio (BCR) is a relative measure which is used to compare benefit per unit of cost. BCR was estimated as a ratio of gross returns to total costs. The formula of calculating BCR (undiscounted) is shown as below:

$$
B C R=\frac{B p v}{C p v}
$$

Where, $\mathrm{BCR}=$ Benefit cost ratio, $\mathrm{B}_{\mathrm{pv}}=$ Gross benefits/returns at present value, and $\mathrm{C}_{\mathrm{pv}}=$ Total cost at present value.

\section{Results and Discussion}

\subsection{Socioeconomic Profile of Turkey Farmers}

Majority (87\%) of the respondents were male, which indicates agricultural farming in Bangladesh is dominant by the male farmers. The national literacy rate was $73.9 \%$ (BBS, 2018) that reflects in this study also; all turkey farmers were highly educated having graduation and above (40\%), and secondary and higher secondary level of education (44\%). It indicates educated farmers are taking the risk of new technology such as turkey farming (Wheeler, 2013). Table 1 also shows that turkey farming is doing by the business group of people (about 56 and $88.57 \%$ respondents had the main and secondary occupation as business, respectively) rather traditional farm households. According to the farm household classification of Department of Agricultural Extension (DAE), most of the turkey farmers (total land holding 183.82 decimals) were belong to the group of small-scale farmers (100 decimals to 249 decimals, BBS, 2018). Having business is the main occupation of the turkey farmers squeezed the farming area of the respondents. 
Table 1. Socioeconomic profile of the turkey farmers

\begin{tabular}{|c|c|c|c|}
\hline Variables & Unit & Category & Value \\
\hline \multirow[t]{2}{*}{ Gender of the respondents } & \multirow[t]{2}{*}{$\%$} & Male & 87 \\
\hline & & Female & 13 \\
\hline \multirow[t]{7}{*}{ Level of education } & \multirow[t]{7}{*}{$\%$} & Illiterate & 0 \\
\hline & & Can read and write & 1 \\
\hline & & Up to secondary level & 15 \\
\hline & & $\mathrm{SSC}^{*}$ & 19 \\
\hline & & $\mathrm{HSC}^{* *}$ & 25 \\
\hline & & Honors & 30 \\
\hline & & Masters & 10 \\
\hline \multirow[t]{5}{*}{ Main occupation } & \multirow[t]{5}{*}{$\%$} & Business & 56 \\
\hline & & Service & 27 \\
\hline & & Farming & 12 \\
\hline & & Housewife & 2 \\
\hline & & Others & 3 \\
\hline \multirow[t]{4}{*}{ Secondary occupation } & \multirow[t]{4}{*}{$\%$} & Business & 88 \\
\hline & & Service & 9 \\
\hline & & Farming & 2 \\
\hline & & Others & 1 \\
\hline \multirow[t]{5}{*}{ Average family members } & \multirow[t]{5}{*}{ No/family } & Adult male & 2.33 \\
\hline & & Adult female & 2.16 \\
\hline & & Male children & 1.23 \\
\hline & & Female children & 1.24 \\
\hline & & Total & 5.75 \\
\hline \multirow[t]{3}{*}{ Average quantity of land holding } & \multirow[t]{3}{*}{ Decimal } & Home purpose land & 24.40 \\
\hline & & Cultivable land & 129.71 \\
\hline & & Non-cultivable land & 29.71 \\
\hline
\end{tabular}

Note: *Scholl Secondary Certificate (after 10 years of education), **Higher Secondary Certificate (after 12 years of education)

\subsection{Farming Practices of Turkey}

\subsubsection{Reasons Behind the Initiatives}

At the beginning of turkey enterprises, price of adult turkey and poults were higher in Bangladesh in comparison to international market. The main reasons were: beginning stage of the turkey subsector, turkeys were sold for ornamental purposes while some buyer bought for farming as well as consumption purposes (Assaduzzaman, 2017). Therefore, Figure 1 shows that majority of the farmers (71\%) started their business for higher profit, followed by farming for loving to rear turkey $(29 \%)$ because of beautiful looking and gamey flavor. 


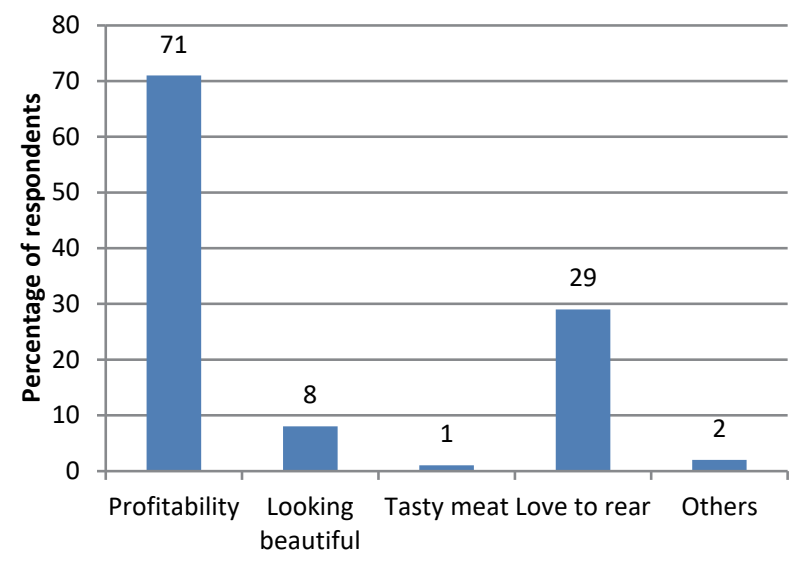

Figure 1. Reasons to start rearing turkey farm

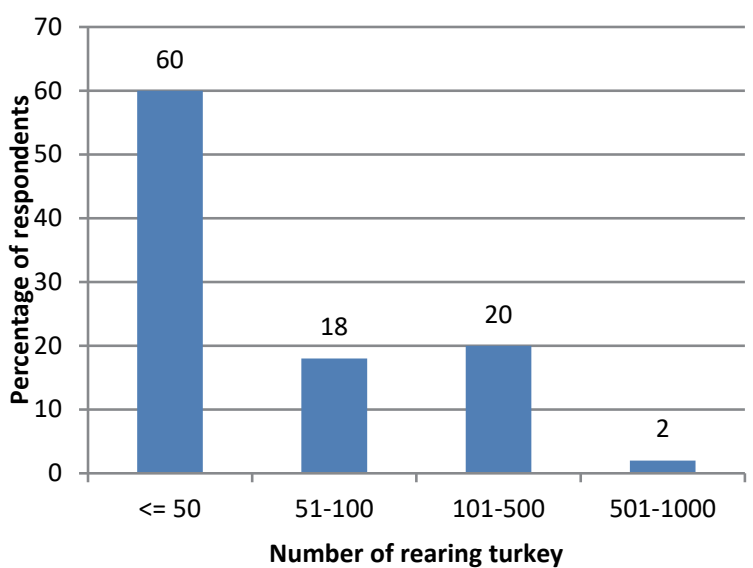

Figure 2. Category of rearing turkey farm

Gradual decreasing of higher profit shaped the size of turkey farming. Figure 2 shows that small scale turkey farming (60\%) is favorable to the farmers. In case of Sudan, Osama et al. (2013) also showed that $66.7 \%$ farmers raised less than 30 birds. Due policies are necessary to improve the situation where farmers can produce turkey with minimum production cost and sell them to the market with reasonable price.

\subsubsection{Turkey varieties}

The most commonly raised commercial varieties, also know as breed, are the American Black and White Holland in Bangladesh. These two breeds occupies the major share (67.98\%) of rearing turkey by the farmers. American Black along with White Holland was dominant because of higher production rate (i.e. higher egg laid and faster weight than other varieties) in Bangladesh (Figure 3). About 55\% respondents respond to American Black as best turkey variety in Sudan (Osama et al., 2013). Some other breeds such as Broad-Breasted Bronze, similar in size and conformation, is less popular because of a preference forblack and white feathering. However, a wide variety of hobby breeds e.g. Red Bourbon, Royal Palm, Beltsville Small White, Silver, Mixed and Quiled colored were also found in defferent parts of the study areas for personal recreation. While nice to look at, most of these hobby strains do not grow as fast and as efficiently as the commercial turkey strains (Hulet et al., 2004).

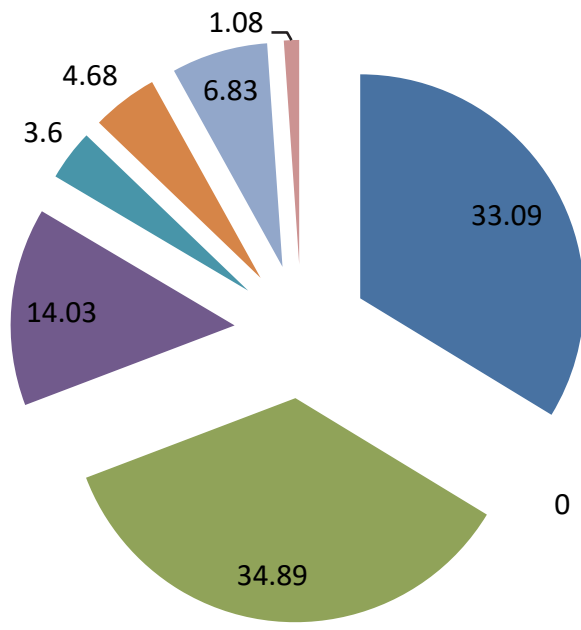

White Holland
Beltsville small white
American Black
Royal Palm
Red Bourbon
Silver colored
Mixed colored
Quail colored

Figure 3. Percentage of rearing turkey variety

\subsubsection{Ratio of Male and Female Turkey at Farm Level}

To ensure the better reproductive rates, appropriate ratio of male and female bird is a perquisite condition of successful farming, if not using the day old chick (DOC) for farming. Table 2 shows that the most used ratio of 
male and female was 1:03 which is about $48.98 \%$ because of very much useful for better reproductive rates. It might be of 1.04 like Sudan where male and female ratio maintained at 1:046 (Osama et al., 2013). It depends on the farmers' experience which combination is suitable for successful reproductive. Even though a good ratio of male and female has less productivity because of absence of frequent mating, heavyweight of male and disturbance during mating (Osama et al., 2013).

Table 2. Ratio of male and female turkey at farm level

\begin{tabular}{ccc}
\hline Ratio of male and female & Number & Percentage \\
\hline $1: 01$ & 4 & 4.08 \\
$1: 02$ & 9 & 9.18 \\
$1: 03$ & 48 & 48.98 \\
$1: 04$ & 19 & 19.39 \\
$1: 05$ & 15 & 15.31 \\
$1: 06$ & 1 & 1.02 \\
$1: 07$ & 1 & 1.02 \\
$1: 08$ & 1 & 1.02 \\
\hline
\end{tabular}

\subsubsection{Turkey Feed, Vaccine and Medicine Management}

Like broiler chicken, turkey requires high protein and other nutrients in their diets. Thus, feed cost represents halve to two-thirds of the total costs in a poultry production system (Mbanasor and Sampson, 2004), therefore it is necessary to identify the animals who eat less but perform at the same level as their contemporaries. Turkeys are good foragers and it could reduce feeding cost through obtain added nutrients from forage because they are better able to digest fiber due to larger microbial population in their digestive tracts (Brad et al., 2010). Figure 4 reveals that highest feed was required for a 20+ weeks aged chick who takes on an average 192.13 grams feed per day, followed by 10-20 weeks aged turkey who takes on an average 132.54 grams feed per day.There is no specific feeding standard for turkey. Farmers used to feed their turkey according to broiler and layer feeding manual (Rahabul, 2018).

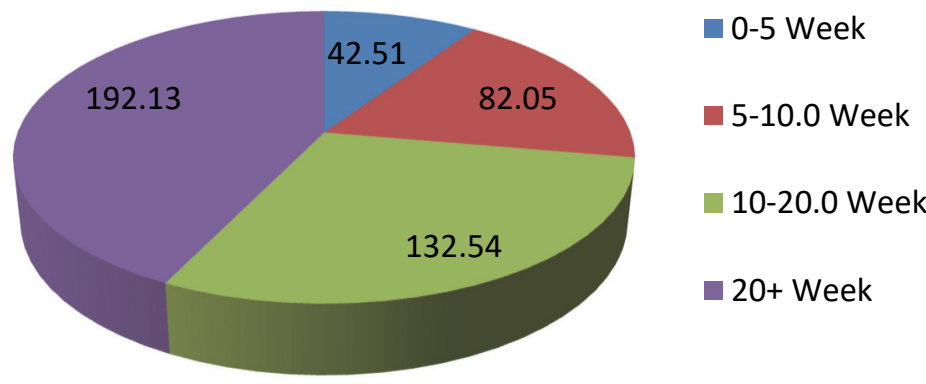

Figure 4. Average feed taken compared to age of turkey

Health management is a key to maintaining the health of turkey flock. Good sanitation, clean stock, clean premises, and elimination of other birds and animals that may carry disease organisms are important for maintaining a healthy flock (Hulet et al., 2004). Genetically, turkey is more resistant to diseases (such as Marek's and infectious bronchitis) than other poultries. Farmers mostly do vaccination only for new castle disease, fowl pox and fowl cholera. Jahan (2018) showed that 36.96\% farmers had encountered diseases like New Castle, Fowl cholera, Fowl pox, Mycoplasmosisetc. Result shows that farmers encountered some deaths $(28 \%)$ of turkey because of Cold, Pox, Ranikhet, Bird flu and unknown diseases in some cases. In that consideration, farmers took advice from various sources such as Upazila Livestock Hospital (69.47\%), private clinic (4.21\%), veterinary surgeon $(2.11 \%)$ 
and remaining from other sources. To avoid the unanticipated deaths of turkey, farmers used different vaccine in the study areas with the consultation of veterinary doctors. Figure 5-9 shows the use of different vaccines by a different portion of farmers at different times.

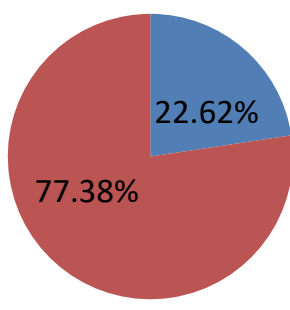

2-7 days

- 5-7 days and 15-25 days

(Twice)

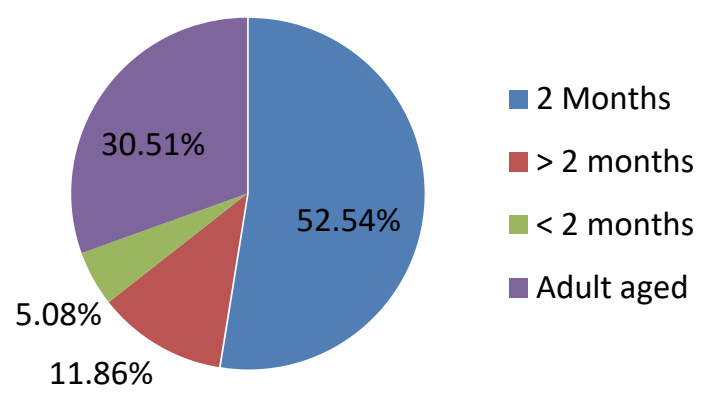

Figure 6. Application time of RDV vaccine

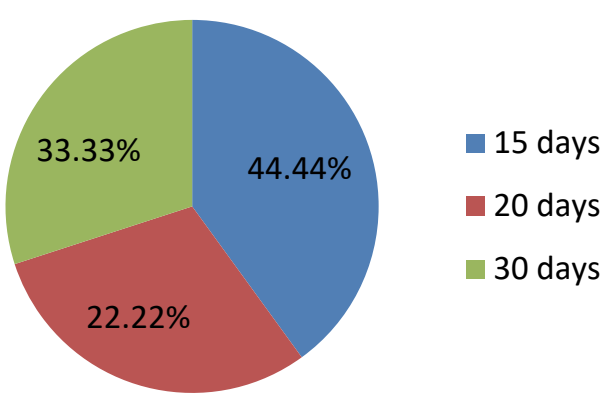

Figure 8. Application time of Gumboro vaccine

Figure 7. Application time of Pox vaccine

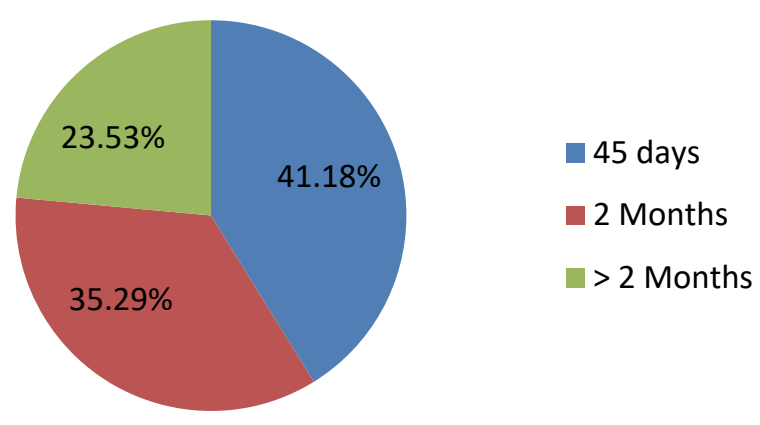

Figure 9. Application time of Cholera vaccine

\subsubsection{Turkey Egg Hatching}

No farmers used artificial insemination (AI) technique and even never heard about the technology used for turkey breeding. White turkey was developed for rapid growth which makes it different from their wild ancestors that they are unable to mate naturally because of their heavyweight and AI has become necessary (Anthony 2001). Table 3 shows that a turkey takes on an average 6.61 months for laying egg and produces 139 egg per year 
irrespective of variety. Majority of respondents $(81.44 \%)$ incubated their egg through hen where average fertility rate is $81.12 \%$ and average hatchability rate is $73.95 \%$. The hatchability rate is higher than average egg hatchability rate (52.85\%) in Tamil Nadu, India (Anandh et al., 2012).

Table 3. Information on hatching of eggs

\begin{tabular}{llll}
\hline Items & Average value & Minimum Value & $\begin{array}{l}\text { Maximum } \\
\text { Value }\end{array}$ \\
\hline Time required for egg laid (months) & 6.61 & 5 & 12 \\
How many times a year (times) & 6.36 & 3 & 8 \\
Number of egg per year & 139 & 100 & 250 \\
Artificial insemination (\%) & 0 & - & - \\
Average value of fertility rate (\%) & 81.12 & 65 & 100 \\
Average value of hatchability rate (\%) & 73.95 & 50 & 90 \\
Incubation of egg through hen (\%) & 81.44 & - & - \\
Incubation of egg through Turkey (\%) & 2.06 & - & - \\
Incubation of egg through both (\%) & 0.00 & - & - \\
Don't incubate the egg (\%) & 16.50 & - & - \\
Having own incubator (\%) & 35 & - & 2000 \\
Average capacity in incubator (no.) & 612.86 & 100 & \\
\hline
\end{tabular}

\subsection{Profitability of Turkey Farming}

The costs and returns and farm net return associated with turkey production in the study area are presented in Table 4. All costs and returns were calculated in BDT per 50 turkeys per year. Cost of feeds $(50.69 \%)$ constituted the highest share of the total cost. Like Bangladesh, cost of feed is the most important variable cost item in turkey production in Nigeria (Emmah, 2006; Mbanasor and Sampson, 2004). Feed cost is higher not only for turkey production, but for other poultry production also because of its higher price in the market as well as the quality of the feed is questionable to some extent also. The cost structure revealed that variable cost constituted almost all costs of the total cost of production of turkey enterprise. In case of calculating interest on operating capital, $5 \%$ interest rate was considered. Generally, the depositor interest rate is around 5-7\%depends on the duration of deposit scheme in Bangladesh. Fixed cost became very low because cheap materials were used for building houses for the birds and reused for many years. Fixed cost was calculated considering the depreciation cost (using the method of straight line) of the housing materials; considered salvage value as $10 \%$ of its starting value for calculating housing cost as depreciation.

Turkey producers generated revenue through the sales of chicks, eggs and adult turkeys. Results revealed that a typical farmer realized a net farm income of BDT 127,838 per 50 turkeys per year indicating that turkey production in the study area is profitable and most of the return (55.67\%) comes from selling chick in this business (Table 4). It was confirmed by the measurement of BCR (1.38) which indicates that farmers get BDT 1.38 in benefits for investing BDT 1.00. Farmers preferred of rearing small flock size (7.26 no./batch) and the average age of turkey of being sold out from the farm when it weighs on an average 5.90 kilograms and the age of 6.30 weeks. Similar study was conducted in Nigeria and found that turkey is profitable provided the farming is efficiently managed (Oluyemi and Roberts, 2000; Emmah, 2006; Ironkwe and Akinola, 2010). 
Table 4. Profitability analysis for 50 turkeys in a year

\begin{tabular}{|c|c|c|}
\hline Cost & $\begin{array}{l}\text { Amount (BDT/50 } \\
\text { turkey/year) }\end{array}$ & $\begin{array}{l}\text { Percentage of total } \\
\text { cost }\end{array}$ \\
\hline \multicolumn{3}{|l|}{ Variable cost } \\
\hline Chick cost & 51682.43 & 15.34 \\
\hline Feed cost & 170770.37 & 50.69 \\
\hline Vaccine and medicine & 16909.98 & 5.02 \\
\hline $\begin{array}{l}\text { Others cost (current bills, watering cost, labor cost, } \\
\text { marketing cost) }\end{array}$ & 79048.60 & 23.47 \\
\hline Interest on operating capital & 15920.57 & 4.73 \\
\hline \multicolumn{3}{|l|}{ Fixed cost } \\
\hline Housing cost (Depreciation) & 2541.86 & 0.75 \\
\hline Total cost (Variable cost + Fixed cost) & \multicolumn{2}{|c|}{336873.31} \\
\hline Return & $\begin{array}{c}\text { Amount (BDT/50 } \\
\text { turkey/year) }\end{array}$ & $\begin{array}{l}\text { Percentage of total } \\
\text { return }\end{array}$ \\
\hline Chick/Poults & 258712.87 & 55.67 \\
\hline Egg & 92716.80 & 19.95 \\
\hline Adult turkey & 113281.68 & 24.38 \\
\hline Profitability analysis & \multicolumn{2}{|c|}{ Amount (BDT/50 turkey/year) } \\
\hline Gross return & \multicolumn{2}{|c|}{464711.35} \\
\hline Gross margin & \multicolumn{2}{|c|}{130379.90} \\
\hline Net return & \multicolumn{2}{|c|}{127838.04} \\
\hline BCR & \multicolumn{2}{|c|}{1.38} \\
\hline
\end{tabular}

\subsubsection{Correlation Analysis}

Seven socioeconomic variables (gender, education, occupation, location of farm, farm size, family members and years of experience) were considered to see the relationship with the profitability of turkey farming. Result revealed that only the variable farmer's experiences of turkey farming has positive significant relationship with the profit in turkey farming (Table 5). This indicates that more experiences in turkey farming provide more profit from turkey production (Maikasuwa et al., 2014).

Table 5. Pearson Product Moment correlation of the relationship between profit in turkey production and socioeconomic variables

\begin{tabular}{lcc}
\hline \multicolumn{1}{c}{ Variables } & r-value & Decision \\
\hline Gender $\left(\mathrm{X}_{1}\right)$ & -0.141 & Insignificant \\
Educational level $\left(\mathrm{X}_{2}\right)$ & 0.156 & Insignificant \\
Occupation $\left(\mathrm{X}_{3}\right)$ & -0.027 & Insignificant \\
Location of farm $\left(\mathrm{X}_{4}\right)$ & 0.112 & Insignificant \\
Farm size $\left(\mathrm{X}_{5}\right)$ & 0.170 & Insignificant \\
Family members $\left(\mathrm{X}_{6}\right)$ & -0.127 & Insignificant \\
Year of experience $\left(\mathrm{X}_{7}\right)$ & 0.385 & Significant \\
\hline
\end{tabular}




\subsection{Supply Chain Mapping}

\subsubsection{Selling of turkey Products}

Figure 10 shows that about $96.89,98.53$ and $97.92 \%$ adult turkey, chick/poults and eggs were sold out from farm respectively, since the marketing channel of turkey is not organized yet. It requires further demand development which will help reshape the marketing channel that will bring more value added products of turkey in near future. Emmah (2006) also found that sales were mainly done at the farm gates using a scale to weigh the adult and poults/chicks of turkey. The average selling price of matured and poults/chicks depend on the size, color, seasons and availability of turkey in study areas.

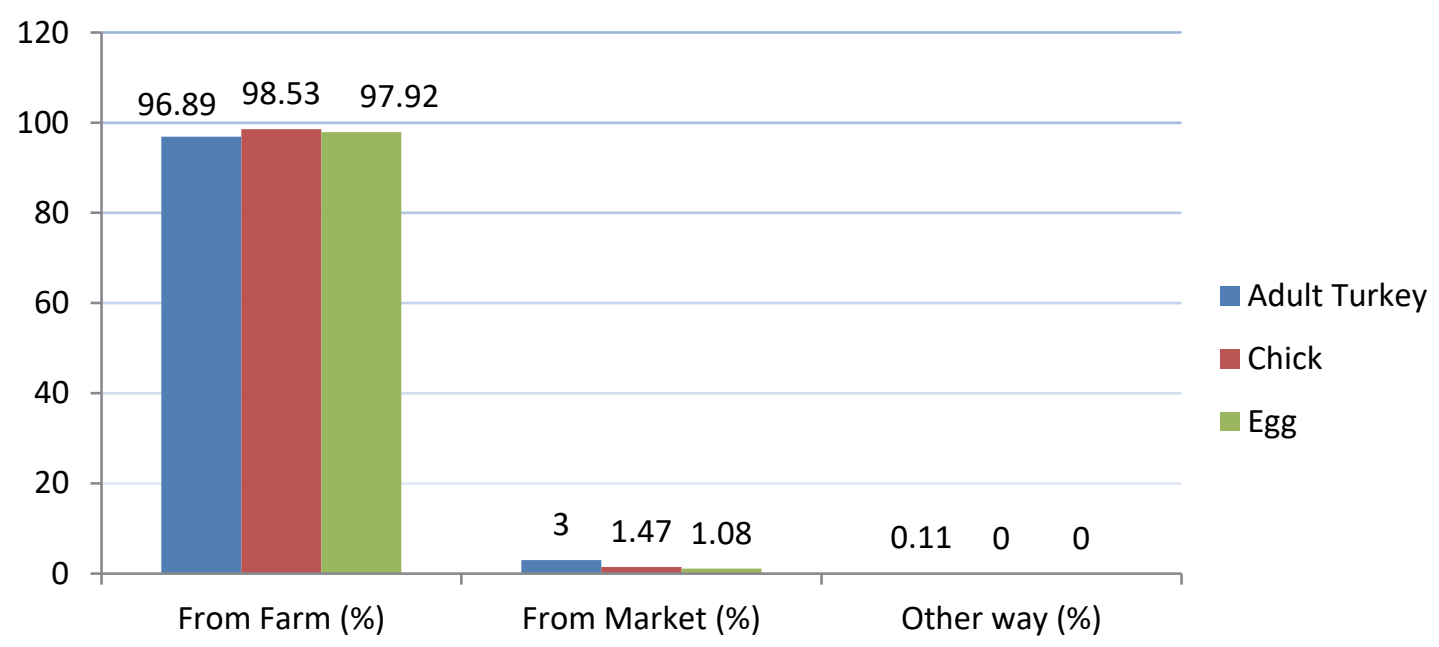

Figure 10. Selling turkey products by different way

\subsubsection{Supply Chain of Turkey Products}

Live bird transaction is very common using direct channel(farmers to consumer) or indirect channel(farmers to middlemen to consumer) where minimal food safety standards of veterinary inspection are implemented (Siddiky, 2018). The available supply chains of turkey are: i) Farmer $\rightarrow$ Wholesaler $\rightarrow$ Retailer $\rightarrow$ Consumer, ii) Farmer $\rightarrow$ Wholesaler $\rightarrow$ Hotels and Restaurant $\rightarrow$ Consumer, iii) Farmer $\rightarrow$ Wholesaler $\rightarrow$ Consumer, iv) Farmer $\rightarrow$ Retailer $\rightarrow$ Consumer, v) Farmer $\rightarrow$ Consumer (Figure 11). Though all channels are not important to the farmers, considering the profit earning, the channel $\mathrm{V}$ that means selling from farm gate was the most important and used channel in the study areas.

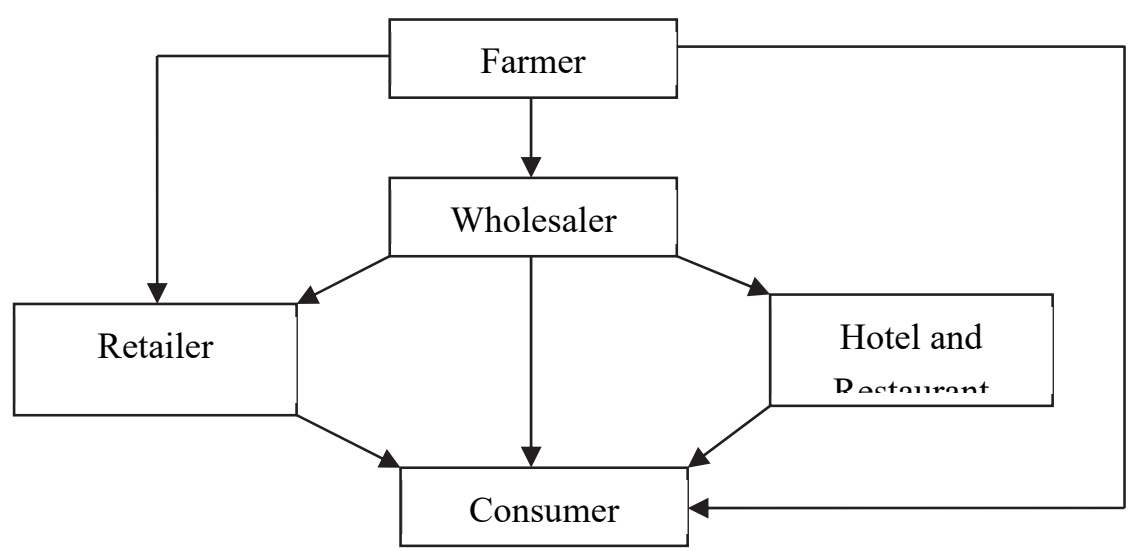

Figure 11. Marketing channel of turkey products 
In addition, channel I, II and IV were also used for adult turkey selling. In case of chick/poults selling, channel I and IV were also used in some areas and channel III and IV were used egg selling. The market intermediaries of turkey supply chain carried out different marketing functions such as buying and selling, pricing, transportation, sorting, distribution, providing market information, etc.

\subsection{Problems and Prospects of Turkey Rearing}

Table 6 shows a wide range of problem were identified by the selected turkey farmers from the different parts of the country. Although the list of problems is long, but it is skewed to three problems such as market instability/price falls $(29.13 \%)$, low feed quality and higher price $(15.22 \%)$ and lack of proper marketing facility (10.87\%). Farmers buy and sell turkey mainly through personal communication. Feed quality and market instability problems were the major problems opined by the turkey farmers in Nigeria and Sudan also (Peters et al.,1997; Osama et al., 2013).

Table 6. Problem faced by farmers in rearing turkey

\begin{tabular}{lc}
\hline \multicolumn{1}{c}{ Statements } & Response rate (\%) \\
\hline Problems & 29.13 \\
\hline Market isn't stable/price falls & 15.22 \\
Feed problem/Lack of quality feed/feed cost is higher & 10.87 \\
Lack of proper marketing facility & 7.83 \\
Lack of medical facility/skilled personnel/veterinary service & 5.65 \\
Lack of diseases controlling ability / huge death faced & 5.22 \\
Inbreeding, fertility and incubation problem & 4.35 \\
Lack of availability of customer for turkey & 3.48 \\
Lack of advertisement or awareness program & 3.48 \\
Lack of availability of training facility & 2.17 \\
Faced huge loss & 3.04 \\
Lack of pure breed in our country & 1.74 \\
Financial inability to buy a turkey weight 3-8 kilograms & 4.35 \\
No problem faced & 3.48 \\
Others & \\
\hline Prospects & 32.74 \\
\hline Production (weight) rate is comparatively higher & 10.71 \\
Profitable business & 10.12 \\
Superior meat and egg quality & 16.67 \\
Diseases rate is lower comparatively & 16.07 \\
Suitable for our country (natural feed, easy to rear, keep calm and looking & \\
beautiful) & 1.79 \\
Egg rate and price is comparatively higher & 11.90 \\
No prospects at all &
\end{tabular}

The farmers found some criteria of turkey farming that have comparative benefits over other types of poultry farming like chicken, duck, quail, etc. Among the influencing criteria, higher weight rate, lower diseases rate, suitability for our country, profitable business, and superior egg and meat quality showed the greater extent of response rate. Some turkey farms stopped their activities because of market price instability during the recent time; and they were asked whether they are interested to re-open the farm again. Majority farmers (28\%) of the shutdown farm opined that they yet wanted to expand and restart their business upon conditioning the stable market price and $7 \%$ wanted to restart in future upon the condition of getting loan. But the alarming fact is that about $39 \%$ respondents haven't any future plan to re-open their farming activities.

\section{Conclusion}

There is a considerable scope of turkey rearing in Bangladesh, as turkey can be reared in free range farming system. It has a good prospects and new dimension in poultry sector. Suitability of climatic condition, availability of natural feed and manpower can make this sector profitable, especially for the poor and marginal farmers. Turkey farmers are facing some production and marketing related problems. Taking proper remedial steps, turkey rearing could 
be a viable commercial enterprise which could play a significant role in poultry sector by supplying nutritious food, generating income, creating employment opportunities and thus improving the living standard of the rural people.

\section{Acknowledgements}

The authors gratefully acknowledged the cooperation of the District Livestock Officer, Upazila Livestock Officer and staffs under the Department of Livestock Services of respective areas and also the farmers for collecting data.

\section{References}

Anandh, M. A., Richard, P. N., Jagatheesan, P., Kumar, S., Paramasivam, A., \& Rajarajan, G. (2012). Effect of rearing systems on reproductive performance of Turkey. Vet. World, 5, 226-229. https://doi.org/10.5455/vetworld.2012.226-229

Anthony, J. S. (2001). Poultry, the tropical agriculturalist series, revised edition, center for tropical veterinary medicine, Univ. Edinb., U.K.

Asaduzzaman, M., Salma, U., Ali, H.S., Hamid, M. A., \& Miah, A. G. (2017). Problems and prospects of turkey (Meleagrisgallopavo) production in Bangladesh. Res. Agric. Livest. Fish., 4(2), 77-90. https://doi.org/10.3329/ralf.v4i2.33719

BBS. (2019). Preliminary Report on Agricultural Census 2019, Bangladesh Bureau of Statistics, Ministry of Planning, Bangladesh.

Besbes, B. (2009). Genotype evaluation and breeding of poultry for performance under sub-optimal village conditions. World's Poultry Science Journal, 65, 260-271. https://doi.org/10.1017/S0043933909000221

Best, J. W., \& Kahn, J. V. (2003). Research in Education (9th ed.). New Delhi: Prentice-Hall of India Private Limited.

Brad, B., Elena, T., \& Gernat, A. (2010). Maximizing foraging behavior, University of Florida, IFAS Extension, pp: $12-13$.

Chowdhury, M. M. I., Ashraf, A., Mondal, S. P., Mondol, M., \&Hasan, M. M. (2004). Effect of season on the hatchability of duck eggs. Int. J. Poult. Sci., 3, 419. https://doi.org/10.3923/ijps.2004.419.421

Crowe, T. M., Bloomer, P., Randi, E., Lucchini, V., Kimball, R.T., Braun, E. L., \& Groth, J. G. (2006). Suprageneric cladistics of landfowl (Order Galliformes). ActaZoologicaSinica, 52(Supplement), 358-36.

DLS. (2019). Annual Progress Report 2018-19, Department of Livestock, Ministry of Fisheries and Livestock, Bangladesh.

Emmah, S. A. (2006). Economic Analysis of Turkey Production in Kaduna and Zaria Towns of Kaduna State, Nigeria, Unpublished M.Sc. Dissertation, Department of Agricultural economics and Rural Sociology, Faculty of Agriculture, Ahmadu Bello University Zaria, Nigeria. Pp.85.

Hulet, R. M., Phillip J. C., George, L. G., Jayson, K. H., \& Lynn, F. K. (2004). Small-Flock Turkey Production, Agriculture Alternatives. Retrieved from https://extension.psu.edu/small-flock-turkey-production

Ironkwe, M. O., \&Akinola, L. F. (2010). Profitability of Turkey Production in Ahoada East ocal Government Area of Rivers State, Nigeria. Continental Journal of Agricultural Science, 4, 38-41.

Jahan, B., Ashraf, A., Rahman, M. A., Molla, M. H. R., Chowdhury, S. H., \& Megwalu, F. O. (2018). Rearing of High Yielding Turkey Poults: Problems and Future Prospects in Bangladesh: A Review. SF J Biotechnol Biomed Eng., 1(2), 1008.

Maikasuwa, M. A., Ala, A. L., \&Baba, M. D. (2014). Economic Analysis of Turkey Production Inzuru Emirate, Kebbi State, Nigeria. Int. J. Modn. Res. Revs., 2(7), 229-234.

Mbanasor, J. A., Sampson, A. (2004). Socio-economic Determinants of Turkey Production among Nigerian Soldiers. International Journal of Poultry Science, 3(8), 497-502.https://doi.org/10.4314/dai.v16i3.15671

MoFL. (2019). Annual Report 2018-19, Ministry of Fisheries and Livestock, Peoples Republic of Bangladesh.

Oluyemi, J. A., \&Roberts, F. A. (2000). Poultry Production in Warm Wet Climates (2nd ed). Spectrum Books Ltd., Ibadan, Nigeria.

Osama, E. Y., Salim, G., Hassan, A. H. A., \& Bushara, A. B. (2013). A Study on Turkey (MeleagrisGallopavo) Raising in the Sudan. Journal of Applied and Industrial Sciences, 1, 11-15

Peters, S. O., Ikeobi, C. O. N., \& Bamkole, O. O. (1997). Smallholder local turkey production in Ogun State, Nigeria, Proceedings of International Network for Family Poultry Development (INFPD), M-Bour, Senegal, 
December 9-13, 1997, pp: 197-208.

Rahabul, I. M. (2018). Rearing system, management practice, problems and prospects of turkey farming in different turkey farms of RangpurSadarUpazila, Internship program for Doctors of Veterinary Medicine (DVM) Degree in Chittagong Veterinary and Animal Sciences University (CVASU), Bangladesh.

Sampath, K. T. (2012). Turkey farming: A profitable enterprise, National Institute of Animal Nutrition and Physiology, Adugodi Bangalore, India, 21, 2.

Siddiky, N. A., ed. (2017). Backyard Poultry Production Systems in SAARC Member States. SAARC Agriculture Centre, Dhaka-1215, Bangladesh.

UNDP/FAO. (1983). Rural poultry improvement project of the government of the People's Republic of Bangladesh. No. BGD/82/003, Project document, Dhaka, Bangladesh.

Wheeler, S., Zuo, A., \& Bjornlund, H. (2013). Farmers' climate change beliefs and adaptation strategies for a water scarce future in Australia. Glob Environ Chang, 23(2), 537-547. https://doi.org/10.1016/j.gloenvcha.2012.11.008

Yakubu, A. K. Abimiku, Musa, I. S. A., Idahor, K. O., \& Akinsola, O. M. (2013). Assessment of flock structure, preference in selection and traits of economic importance of domestic turkey (Meleagrisgallopavo) genetic resources in Nasarawa state, Nigeria. Livestock Research for Rural Development, 25, 18.

\section{Copyrights}

Copyright for this article is retained by the author(s), with first publication rights granted to the journal.

This is an open-access article distributed under the terms and conditions of the Creative Commons Attribution license (http://creativecommons.org/licenses/by/4.0/). 